Routledge Advances in Translation and Interpreting Studies

\title{
TRANSLATION AND EMOTION
} A PSYCHOLOGICAL PERSPECTIVE

Séverine Hubscher-Davidson

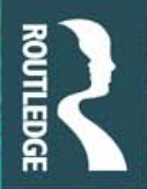




\section{Translation and Emotion}

An excellent and timely overview of translation and emotion, a topic that corresponds to recent developments in translation process research yet has previously not been addressed in any great depth. It is innovative, original and a highly recommended read for scholars, teachers and students of translation, translators, and also for linguists and psychologists.

-Hanna Risku, University of Graz, Austria

This book proves that translators are not mere neutral word crunchers and looks under the hood of their minds to unveil a complex interplay between reason and emotion that both affects and is affected by their work.

-Ricardo Muñoz Martín, Universidad de Las Palmas de Gran Canaria, Spain

This volume tackles one of the most promising and interdisciplinary developments in modern Translation Studies: the psychology of translation. It applies the scientific study of emotion to the study of translation and translators in order to shed light on how emotions can impact decision-making and problem-solving when translating. The book offers a new critical approach to the study of emotion in translation by analysing translators' accounts of their experiences, as well as drawing on a case study of emotional intelligence involving 155 professional translators. The author identifies three distinctive areas where emotions influence translators: emotional material contained in source texts, their own emotions, and the emotions of source and target readers. In order to explore the relevance and influence of emotions in translation, each chapter focuses on a different emotion trait: emotion perception, emotion regulation, and emotion expression.

Séverine Hubscher-Davidson is Head of Translation at The Open University (UK). She is the author of several peer-reviewed articles on translators' psychological processes, tackling topics such as translators' ambiguity tolerance and intuition. She has also co-edited books on cognitive processes in translation and translator education. 


\section{Routledge Advances in Translation and Interpreting Studies}

For a full list of titles in this series, visit www.routledge.com/RoutledgeAdvances-in-Translation-and-Interpreting-Studies/book-series/RTS

23 Translation and Public Policy

Interdisciplinary Perspectives and Case Studies

Edited by Gabriel González Núñez and Reine Meylaerts

24 Translationality

Essays in the Translational-Medical Humanities

Douglas Robinson

25 The Changing Role of the Interpreter

Contextualising Norms, Ethics and Quality Standards

Edited by Marta Biagini, Michael S. Boyd and Claudia Monacelli

26 Translation in Russian Contexts

Culture, Politics, Identity

Edited by Brian James Baer and Susanna Witt

27 Untranslatability Goes Global

Edited by Suzanne Jill Levine and Katie Lateef-Jan

28 Queering Translation, Translating the Queer

Theory, Practice, Activism

Edited by Brian James Baer and Klaus Kaindl

29 Translating Foreign Otherness

Cross-cultural anxiety in modern China

Yifeng Sun

30 Translating Picturebooks

Revoicing the Verbal, the Visual and the Aural for a Child Audience

Riitta Oittinen, Anne Ketola and Melissa Garavini

31 Translation and Emotion

A Psychological Perspective

Séverine Hubscher-Davidson 


\title{
Translation and Emotion A Psychological Perspective
}

\author{
By Séverine Hubscher-Davidson
}

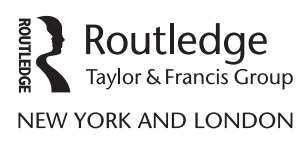


First published 2018

by Routledge

711 Third Avenue, New York, NY 10017

and by Routledge

2 Park Square, Milton Park, Abingdon, Oxon OX14 4RN

Routledge is an imprint of the Taylor \& Francis Group, an informa business

(C) 2018 Taylor \& Francis

The right of Séverine Hubscher-Davidson to be identified as author of this work has been asserted by her in accordance with sections 77 and 78 of the Copyright, Designs and Patents Act 1988.

The right of the editor to be identified as the author of the editorial material, and of the authors for their individual chapters, has been asserted in accordance with sections 77 and 78 of the Copyright, Designs and Patents Act 1988.

All rights reserved. No part of this book may be reprinted or reproduced or utilised in any form or by any electronic, mechanical, or other means, now known or hereafter invented, including photocopying and recording, or in any information storage or retrieval system, without permission in writing from the publishers.

Trademark notice: Product or corporate names may be trademarks or registered trademarks, and are used only for identification and explanation without intent to infringe.

Library of Congress Cataloging-in-Publication Data A catalog record for this book has been requested

ISBN: 978-1-138-85533-5 (hbk)

ISBN: 978-1-315-72038-8 (ebk)

Typeset in Sabon

by Apex CoVantage, LLC 


\section{Contents}

List of Figures vii

List of Tables ix

List of Abbreviations xi

Acknowledgements xiii

Introduction 1

1 Emotion and the Translation Process 9

2 Emotion Perception 65

3 Emotion Regulation 107

4 Emotion Expression 147

5 Discussion 195

$\begin{array}{ll}\text { Conclusion and Future Directions } & 217\end{array}$

$\begin{array}{ll}\text { Appendices } & 225\end{array}$

$\begin{array}{ll}\text { Index } & 229\end{array}$ 
$\because$ Taylor \& Francis

Taylor \& Francis Group

http://taylorandfrancis.com 


\section{Figures}

1.1 Simplified mapping of study concepts onto three existing traditions of emotion theories

1.2 The factors and facets of the TEIQue

1.3 Visual representation of the TEIQue factors and facets

3.1 Process model of emotion regulation

4.1 Process model of emotion expression 
$\because$ Taylor \& Francis

Taylor \& Francis Group

http://taylorandfrancis.com 


\section{Tables}

1.1 Operationalising the study variables 43

1.2 TEIQue means, standard deviations, and effect sizes 48

2.1 Different emotion theories and their conceptualisations of emotional stimuli categorisation 66

2.2 Emotion perception, emotionality, and professional translators' sociobiographical variables (Pearson's $r$ ) 89

3.1 Emotion regulation processes and strategies 109

3.2 Emotion regulation, self-control, and professional translators' sociobiographical variables (Pearson's $r$ )

4.1 Emotion expression, emotionality, and professional translators' sociobiographical variables (Pearson's $r$ ) 
$\because$ Taylor \& Francis

Taylor \& Francis Group

http://taylorandfrancis.com 


\section{Abbreviations}

CPD continuing professional development

L1, L2 first, second acquired language

EI emotional intelligence

PTSD post-traumatic stress disorder

ST source text

TEIQue Trait Emotional Intelligence Questionnaire

TAP Think Aloud Protocol

TPR translation process research

TT target text 
$\because$ Taylor \& Francis

Taylor \& Francis Group

http://taylorandfrancis.com 


\section{Acknowledgements}

I would like to thank members of the TREC research network for their continued enthusiasm and support for my research. Their rigorous feedback, challenging questions, and helpful suggestions at workshops and conferences contributed toward the development of my thinking on this topic and were at the forefront of my mind when writing this monograph. Special thanks also go to the three anonymous readers for Routledge whose judicious critical comments helped to shape the present work. I am also thankful for the continuous advice and encouragement provided by Professor Christina Schäffner over the years.

I very gratefully acknowledge the invaluable contributions of friends, colleagues, students, and, especially, the professional translators who volunteered their time to take part in the case study. I also thank Professor Dino Petrides for his helpful comments in the early stages of this research. I am extremely grateful to Matthias Apfelthaler for his interest in this work and insightful suggestions in moments of doubt; to Tom Gale, who provided a unique professional perspective on the issues raised; and to Claudine Borg for her confidence in me.

As always, I am thankful for my family's love and their moral and intellectual support over the years. In particular, I am deeply grateful to my husband Steve who keeps me on an even emotional keel. Without his unstinting love and support, this book would not have seen the light of day. 
$\because$ Taylor \& Francis

Taylor \& Francis Group

http://taylorandfrancis.com 


\section{Introduction}

Everyone knows the difficulty of things that are exquisite and well done-so to have facility in such things gives rise to the greatest wonder.

—Baldesar Castiglione

\section{Preamble}

Laure's inert body, the enchantment she saw on her daughter's impassive face, caused extremely intense emotions over which she had no control to well up in her. She was submerged by a primitive force that burst forth, whipping her, harassing her, slashing her . . . Hatred! Hatred was a Florentine cypress, tall, dark, pointed, slim. It towered over the welter of feelings ... If not for Laure at the other end of the flat, soft as an overripe fruit, rotten with drugs, she would have killed Alex.

—Cardinal (1991, 80-81)

On reading this extract from Marie Cardinal's Devotion and Disorder, one of the first questions that comes to mind is, how did the author feel when writing this text? Did she identify with the character/narrator, Laure's mother? Did she write from personal experience? We might also wonder how readers are likely to feel when reading the text. How will they react? Will they perceive the character's emotions in the way intended by the author, or will their reading experience affect them differently? Narrative research has shown that reader responses vary from person to person as a result of particular histories and differences in life experiences that determine how they evaluate characters' motives, decisions, and behaviours (Jacovina and Gerrig 2010). We might therefore wonder about the range of reactions to a text with such a strong emotional component. Moreover, since this text is a translation, another question we could ask ourselves is how well does the emotional component translate for another cultural context? Reader responses to emotions vary across the world, and readers of the French or Chinese version will respond to and understand the narrative differently. And what about the translators? How do they relate to the text and to the translation task? As readers of the originals and writers of the translations, their emotional responses are likely to be essential ingredients 


\section{Introduction}

in the shaping of different language versions. The main aim of this book is thus to demonstrate the implications of emotionality for translation work and to explore the relevance and influence of emotions in translation by focusing on specific emotion traits.

This book therefore bridges two fields of research: Translation Studies and Affective Science. Drawing on a case study involving 155 translators, it will explore affective aspects of translation by applying the scientific study of emotion to the study of translators. As Jean Anderson highlights, relatively little work exists which documents or analyses translators' affective interface with their work $(2005,179)$. In an attempt to fill this gap, an analysis of the emotional intelligence of translators will be undertaken, focusing on three specific emotion traits: emotion perception, emotion regulation, and emotion expression. The methods used include an emotional intelligence measure which has been employed in various research contexts, including second-language acquisition and creative writing.

The idea for this book originated from the fact that, although interdisciplinary research has fast become the norm in Translation Studies, ${ }^{1}$ the role of the translator's emotions from an affective perspective has remained almost entirely unexplored. Recent studies investigating the translation process have borrowed models and frameworks extensively from the cognitive sciences ${ }^{2}$ to the detriment of research falling under the broad umbrella of Affective Science. The majority of studies that have investigated the topic of emotions in translation are overwhelmingly concerned with how emotional material or emotive language is being translated. ${ }^{3}$ Research shows, however, that emotions are involved in all kinds of decision-making and problem-solving behaviours, and one can argue that there are three distinctive areas where emotions influence translators: emotional material contained in source texts, their own emotions, and the emotions of source and target readers. The first area involves emotion perception, the second area involves emotion regulation, and the third area involves emotion expression. This book therefore seeks to explore further the translator's handling of these emotions by investigating specific aspects of translators' trait emotional intelligence profiles.

Traditionally muted, self-effacing and non-interfering, translators' voices have recently become louder, persistent, and sometimes unsettling. If one defines emotionality as a set of responses that are observable or perceivable to us or to others around us and take place when a person reacts emotionally to stimuli (Rajah, Song, and Arvey 2011, 1107) one cannot but acknowledge the role of emotionality in translators' work. Anderson $(2005,177)$ speaks of a sense of physical invasion by the original text and a need to 'choke down' rebellious feelings when translating. Another translator speaking at the American Translator's Association Conference in 2009 shared her reaction to translating an autopsy report:

This was not the first of this kind of report that I had dealt with, but it was the most horrific. The crime was so terrible that the perpetrator 
was sentenced to 102 years and permanent separation from society. There may be a literature of how coroners deal with the actual autopsy, but I found nowhere to turn except to a fellow translator who could understand how a text could reach so far into me.

(Jones 2009)

Translators' emotional reactions to source texts such as these are rarely discussed and, more often than not, translators deal with them on their own and to the best of their ability. When discussing her own experience as a literary translator, Hills notes,

I had to draw on all my skills as a writer to render hers as effectively as I could, and yet, at the same time, I needed to strike a balance [. . . ] especially as I had recently written a novel that also dealt with grieving and had a strong sense of how I had handled similar themes and states.

$(2012,84)$

Peter Bush $(2012,122)$ highlights instances of fraught relationships between translators and editors, reflecting the level of emotional and intellectual commitment of translators to their work. This study demonstrates that the way in which translators perceive, regulate, and transfer emotional material impacts them and target texts in specific ways, not all of these negative. Indeed, translators like Anne Jones suggest that some texts are a delight to translate and can serve to nurture and activate the full self of the translator.

The benefits of adding a psychological perspective in Translation Studies have been acknowledged for some time. Process-based studies have employed various methods (eye tracking, keyboard logging, thinking aloud, etc.) to investigate translator behaviour and the translation process. However, translation process research (TPR) —an offshoot of Holmes's (2000/1972) descriptive sub-branch of 'pure' Translation Studies-has generally focused on exploring translators' mental processes and human information processing skills (Bell 2001). This book argues that, alongside the study of purely cognitive processes, the psychology of translation must also encompass the study of attitudes, personalities, and dispositions.

\section{Emotionality: Author, Translator, Reader}

Recent studies have subscribed to the view that, more than a product, translation is an activity that serves to bring into being the potentialities of a source text through a target text (Wilson and Gerber 2012, ix). Arguably, the potentialities of source texts are also brought into being through the translator's effortful activity. Translators undertake very close readings of source texts and become involved with source authors and their texts to a greater extent than do 'regular' target readers. It can be said that the translation process binds them to source authors, providing them with intimate knowledge of how they work, how they construct meanings, impart 


\section{Introduction}

knowledge and express themselves. If the work they are engaged so closely with happens to contain explosive emotion-eliciting material, the translator may become destabilised, shaken, unsure, fearful even. Hills (2012, 77) suggests that entering into translation is like entering into a relationship, and that, through contact with the language of others, translators can get a greater sense of themselves. I would argue that this also holds true for emotions. Contact with the emotions of others can bring about an increase in the understanding and regulating of one's own emotions. And yet, there is also a risk of completely losing oneself in another's emotions. The wellknown metaphor of the translator walking a tightrope springs to mind.

Despite the constraints within which they work, translators are not victims. Like Anderson (2005, 178), one might wonder whether the translator is not actually the primary driver of his or her own creation, the translation. When perceiving, regulating and transferring emotions in writing, the translator shapes a text that takes into account vast amounts of emotional information including the potential reactions of target readers, as the reception and understanding of translated emotions will necessarily differ from one culture to another. They are responsible for carrying over specific, personal, affective, identity-related otherness. They drive the creation of a text that will expose and give scope to new significances and intertextualities (Henitiuk 2012, 4).

This critical activity involves a double interpretation process. Let us assume that a translator has been given a source text containing complex emotioneliciting content written in his or her second language (L2). First, he or she must adequately understand and interpret it; second, he or she must engage with a different language in an attempt to re-express this complex emotioneliciting content. According to Henitiuk, our senses cannot always be trusted to pass along information reliably when what we perceive, receive, and rewrite comes from a different culture and world view (ibid., 9). Inevitably, translators will need to tap into their own resources of emotional experiences and emotional language in order to understand and transfer the information to the best of their abilities. As Hills highlights, translating emotional material forces one to explore emotions and language on a deeper level, intensely, to find ways to communicate what is core in a piece, to "learn how to breathe again" $(2012,80)$. This two-stage process transforms the translator into both a therapist and a patient. As such, the translator will perform the necessary actions of both: perceiving and understanding, on one hand, and expressing emotions arising from the translation event, on the other.

In order to do this competently, the translator needs to have what Anderson terms "the ability to open oneself to the foreignness of another language at the level of one's personality" $(2005,175)$. As I argue in this book, translators who can also open themselves to their own and others' emotions will be much more likely to succeed in the translation profession. This book is therefore concerned with the perception, regulation, and expression of 
emotions by translators. It aims to offer a new critical approach to the study of emotion in translation by drawing on translators' narratives and on a case study of emotional intelligence involving 155 translators, in order to highlight moments when there is an interference of individual differences during the translation process.

\section{Outline}

In the first chapter, I provide context for the study by presenting the theoretical background to the scientific study of emotion in the field of Psychology. Affective and cognitive approaches are discussed, including the notion of emotional intelligence and its measurement. I present key issues in the field (e.g. validity and consistency) and demonstrate the importance of employing reliable methods to analyse emotions. I also present an overview of the development of psychological approaches to the study of translation within Translation Studies. I focus on methods developed to analyse the translation process with a particular emphasis on soft skills and their implications for the field. This theoretical background draws on the most influential works within Translation Studies and Psychology and serves to contextualise the case study, which is also explained in detail.

In the following chapters, three specific emotion traits are discussed at length: emotion perception (Chapter 2), emotion regulation (Chapter 3) and emotion expression (Chapter 4). These traits were presumed to be the most relevant for translation. Each chapter contains a definition and an explanation within Affective Science of the key trait, a section addressing the relevance of this particular trait for translation (drawing on both the translation and psychology literature), and an analysis and discussion of the expression of that trait in the profiles of translators from the case study. ${ }^{4}$

In the final chapter, I undertake a summary analysis and discussion of key findings from the previous chapters and the case study to draw out how, why, and when emotions influence the translator. The different areas where emotions have a role are discussed, and important questions are addressed, such as whether traits can be developed over time and what are the consequences for translators of (un)successful emotional functioning.

The conclusion reviews the book's achievements and suggests avenues for further research.

\section{Notes}

1 See, for example, the flurry of recent conferences that attest to this interdisciplinarity (e.g. 'First International Interdisciplinary Conference on Bridging Languages and Cultures', 14-15 September 2017, Ventspils University; 'Interdisciplinary Approaches to Translation', 27-28 March 2014, Kazimierz Wielki University; 'International Conference on Interdisciplinary Translation Studies', 30 April-2 May 2013, Imam Reza International University). 


\section{Introduction}

2 Examples of two recent publications that bridge these disciplines are Shreve and Angelone (2010) and Ehrensberger-Dow et al. (2013).

3 See, for example, Lee (2003) or Wittwer (2007).

4 Chapter 2 pays particular attention to translators' perception of emotional material contained in source texts, Chapter 3 tackles translators' emotion regulation processes, and Chapter 4 focuses on translators' expression of emotions for target readers.

\section{References}

Anderson, Jean. 2005. “The Double Agent: Aspects of Literary Translator Affect as Revealed in Fictional Work by Translators”. Linguistica Antverpiensa 4: 171-182.

Bell, Roger. 2001. "Psycholinguistic/Cognitive Approaches". In Routledge Encyclopedia of Translation Studies, 1st edition, edited by Mona Baker, 242-248. London and New York: Routledge.

Bush, Peter. 2012. "Toil, Trouble and Jouissance: A Case-Study-Editing Juan the Landless". In Creative Constraints: Translation and Authorship, edited by Rita Wilson and Leah Gerber, 119-131. Clayton, VIC: Monash University Publishing.

Cardinal, Marie. 1991. Devotion and Disorder: A Story of Addiction, Obsession and Maternal Love [Les Grands Désordres]. Translated by K. Montin. London: The Women's Press Ltd.

Castiglione, Baldesar. 1959. The Book of the Courtier. Translated by Charles S. Singleton. Garden City: Anchor Books.

Ehrensberger-Dow, Maureen, Birgitta Englund Dimitrova, Séverine HubscherDavidson and Ulf Norberg. (eds.) 2013. Describing Cognitive Processes in Translation: Acts and Events. Amsterdam and Philadelphia: John Benjamins Publishing Company.

Henitiuk, Valerie. 2012. "Optical Illusions? Literary Translation as a Refractive Process". In Creative Constraints: Translation and Authorship, edited by Rita Wilson and Leah Gerber, 3-20. Clayton, VIC: Monash University Publishing.

Hills, Lia. 2012. "Effective Self-Translation: How Not to Completely Lose Yourself in Another's Language". In Creative Constraints: Translation and Authorship, edited by Rita Wilson and Leah Gerber, 77-84. Clayton, VIC: Monash University Publishing.

Holmes, James S. 2000/1972. “The Name and Nature of Translation Studies”. In The Translation Studies Reader, edited by Lawrence Venuti, 172-185. London and New York: Routledge.

Jacovina, Matthew E., and Richard Gerrig J. 2010. "How Readers Experience Characters' Decisions". Memory and Cognition 38(6): 753-761.

Jones, Anne. 2009. “The Translator's Self”. Paper presented at the American Translators Association 50th Annual Conference, October 28-31, New York City.

Lee, Hyeseung. 2003. "Analysis of Russian-Korean Translation of Emotion Metaphor”. Conference Interpretation and Translation 5(1): 183-200.

Rajah, Rashimah, Zhaoli Song, and Richard D. Arvey. 2011. "Emotionality and Leadership: Taking Stock of the Past Decade of Research". The Leadership Quarterly 22: 1107-1119.

Shreve, Gregory and Erik Angelone. (eds.) 2010. Translation and Cognition: American Translators Association Scholarly Monograph Series 15. Amsterdam and Philadelphia: John Benjamins Publishing Company. 
2012. "Introduction". In Creative Constraints: Translation and Authorship, edited by Rita Wilson and Leah Gerber, ix-xv. Clayton, VIC: Monash University Publishing.

Wittwer, Michael. 2007. "Emotion and Translation: Using the Example of Popularising Medical Texts in Paediatrics". In Evidence-Based LSP: Translation, Text and Terminology, edited by Ahmad Khurshid and Margaret Rogers, 345-356. Bern: Peter Lang. 
$\because$ Taylor \& Francis

Taylor \& Francis Group

http://taylorandfrancis.com 


\section{References}

\section{Introduction}

Anderson, Jean. 2005. "The Double Agent: Aspects of Literary Translator Affect as Revealed in Fictional work by Translators". Linguistica Antverpiensa 4: 171-182.

Bell, Roger. 2001. "Psycholinguistic/Cognitive Approaches". In Rout ledge Encyclopedia of Translation Studies, 1st edition, edited by Mona Baker, 242-248. London and New York: Rout ledge.

Bush, Peter. 2012. "Toil, Trouble and Jouissance: A Case-Study-Editing Juan the Landless". In Creative Constraints: Translation and Authorship, edited by Rita Wilson and Leah Gerber, 119-131. Clayton, VIC: Monash University Publishing.

Cardinal, Marie. 1991. Devotion and Disorder: A Story of Addiction, obsession and Maternal Love [Les Grands Désordres]. Translated by K. Montin. London: The Women's Press Ltd.

Castiglione, Baldesar. 1959. The Book of the Courtier. Translated by Charles S. Singleton. Garden City: Anchor Books.

Ehrensberger-Dow, Maureen, Birgitta Englund Dimitrova, Séverine HubscherDavidson and ulf Norberg. (eds.) 2013. Describing Cognitive Processes in Translation: Acts and Events. Amsterdam and Philadelphia: John Benjamins Publishing Company.

Henitiuk, Valerie. 2012. "Optical Illusions? Literary Translation as a Refractive Process". In Creative Constraints: Translation and Authorship, edited by Rita Wilson and Leah Gerber, 3-20. Clayton, VIC: Monash University Publishing.

Hills, Lia. 2012. "Effective Self-Translation: How Not to Completely Lose Yourself in Another's Language". In Creative Constraints: Translation and Authorship, edited by Rita Wilson and Leah Gerber, 77-84. Clayton, VIC: Monash University Publishing.

Holmes, James S. 2000/1972. "The Name and Nature of Translation Studies". In The Translation Studies Reader, edited by Laurence Venuti, 172-185. London and Neu York: Rout ledge. 
Jacovina, Matthew E., and Richard Gerrig J. 2010. "How Readers Experience Characters' Decisions". Memory and Cognition $38(6)$ : 753-761.

Jones, Anne. 2009. "The Translator's Self". Paper presented at the American Translators Association 50th Annual Conference, October 28-31, New York City.

Lee, Hyeseung. 2003. "Analysis of Russian-Korean Translation of Emotion Metaphor". Conference Interpretation and Translation 5(1): 183-200.

Rajah, Rashimah, zhaoli song, and Richard D. Arvey. 2011. "Emotionality and Leadership: Taking Stock of the Past Decade of Research". The Leadership Quarterly 22: 1107-1119.

Shreve, Gregory and Erik Angelone. (eds.) 2010. Translation and Cognition: American Translators Association Scholarly Monograph Series 15. Amsterdam and Philadelphia: John Benjamins Publishing Company.

-. 2012. "Introduction". In Creative Constraints: Translation and Authorship, edited by Rita Wilson and Leah Gerber, ix-xv. Clayton, VIC: Monash University Publishing.

Wittwer, Michael. 2007. "Emotion and Translation: Using the Example of Popularising Medical Texts in Paediatrics". In Evidence-Based LSP: Translation, Text and Terminology, edited by Ahmad Khurshid and Margaret Rogers, 345-356. Bern: Peter Lang. 


\section{Emotion and the Translation Process}

Brasseur , Sophie, Jacques Grégoire, Romain Bourdu, and Moira Mikolajczak. 2013. "The Profile of Emotional Competence (PEC): Development and Validation of a Self-Reported Measure that Fits Dimensions of Emotional Competence Theory". PLos one 8(5): e62635. The British Psychological Society. 2014. Test Revieu-Trait Emotional Intelligence questionnaire (TEIQue). Leicester: BPS Psychological Testing Centre. Brounlie, Siobhan. 2016. Mapping Memory in Translation. Basingstoke and New York: Palgrave Macmillian. Bryman, Alan. 2008. Social Research Methods. 3rd edition. 0xford: 0xford University Press. Chamorro-Premuzic, Tomas, Sophie von Stumm, and Adrian Furnham. (eds.) 2011. The Wiley-Blackuell Handbook of Individual Differences. vol. 3. Chichester: Wiley Blackuell. CILT, the National Centre for Languages. 2007. National 0ccupational Standards in Translation. Accessed August 2017. http://ulul.skillscfa.org/images/

Ehrensberger-Dow, Maureen, and Sharon 0'Brien. 2015. "Ergonomics of the Translation Workplace". Translation Spaces 4(1): $98-118$.

Englund Dimitrova, Birgitta. 2005. Expertise and Explicitation in the Translation Process. Amsterdam and Philadelphia: John Benjamins.

Feltrin-Morris, Marella. 2012. "The Art Concealed". In Translation and Literary Studies: Homage to Marilyn Gaddis Rose, edited by Marella Feltrin-Morris, Deborah Folaron, and Maria Constanza Guzmán, 69-76. Manchester and Kinderhook: St. Jerome Publishing. Ferrando, Mercedes, Maria Dolores Prieto, Leandro S. Almeida, Carmen Ferrandiz, Rosario Bermejo, José Antonio López-Pina, Daniel Hernändez, Marta Sainz, and Mari-Carmen Fernändez. 2011. "T rait Emotional Intelligence and Academic Performance: Controlling for the Effects of IQ, Personality, and Self-Concept". Journal of Psychoeducational Assessment 29: 150-159. Ferreira, Aline, John w. Schwieter, and Daniel Gile. 2015. "The Position of Psycholinguistic and Cognitive Science in Translation and Interpreting: An Introduction". In Psycholinguistic and Cognitive Inquiries into Translation and Interpreting, edited by Aline Ferreira, John w. Schwieter, and Daniel Gile, 3-16. Amsterdam and Philadelphia: John Benjamins. Fiske, Susan T., and shelley E. Taylor. 2013. Social Cognition: From Brains to Culture. Second edition. London: Sage. Fraser, Janet. 1996. "The Translator Investigated: Learning from Translation Process Analysis". The Translator 2(1): 65-79. ㄴ. 2000. "What Do 
Real Translators Do? Developing the Use of TAPS from Professional Translators". In Tapping and Mapping the Processes of Translation and Interpreting, edited by Riitta Jääskeläinen and Sonja Tirkkonen-Condit, 111- 123. Amsterdam and Philadelphia: John Benjamins. Frijda, Nico H. 2008. "The Psychologists' Point of Vieu". In Handbook of Emotions, Third edition, edited by Michael Lewis, Jeannette M. Haviland-Jones, and Lisa Feldman Barrett, 68-87. New York and London: The Guilford Press. Frijda, Nico H. and Klaus R. Scherer. 2009. "Emotion Definitions (Psychological Perspectives)". In The Oxford Companion to Emotion and the Affective sciences, edited by David Sander and Klaus R. Scherer, 142-144. 0xford: Oxford University Press. Furmanek, 0lgierda. 2005. Emotions and Language choices in Multilingual Discourse. Kraków: Księgarnia Akademicka. Gaddis Rose, Marilyn. 2012. "Celebrating the Inevitable". In Translation and Literary Studies: Homage to Marilyn Gaddis Rose, edited by Feltrin-Morris, Marella, Deborah Folaron, and Maria Constanza Guzmän, 25-31. Manchester and Kinderhook: St. Jerome Publishing. Gardner, Howard. 1983. Frames of Mind. New York: Basic Books Inc.

Gökçen, Elif, Adrian Furnham, Stella Mavroveli, and K. V. Petrides. 2014. "A Crosscultural Investigation of Trait Emotional Intelligence in Hong Kong and the UK". Personality and Individual Differences 65: 30-35. Goleman, Daniel. 1995. Emotional Intelligence. New York: Bantam Books Göpferich, Susanne. 2013. "Translation Competence: Explaining Development and Stagnation from a Dynamic Systems Perspective". Target: International Journal of Translation Studies 25(1): 61-76. Gross, James. 2008. "Emotion and Emotion Regulation: Personality Processes and Individual Differences". In Handbook of Personality, edited by Oliver $P$. John, Richard $W$. Robins, and Laurence $A$. Pervin, 701-724. New York: The Guildford Press. Halverson, Sandra. 2014. "Reorienting Translation Studies: Cognitive Approaches and the Centrality of the Translator". In Translation: A Multidisciplinary Approach, edited by Juliane House, 116-139. Basingstoke: Palgrave Macmillan. -. 2017. "Multimethod Approaches". In Handbook of Translation and Cognition, edited by John W. Schweiter and Aline Ferreira, 195-212. Hoboken: Wiley-Blackwell. Hammersley, Martyn, and Paul Atkinson. 2007. Ethnography: Principles in Practice. Abingdon and New York: Routledge. Hansen, Gyde. 2005. "Experience and Emotion in Empirical Translation Research with Think-Aloud and Retrospection". Meta: Translators' Journal 50(2): 511-521. -. 2006. "Retrospection Methods in Translator Training and Translation Research". Journal of Specialised Translation 5(1): 2-41. - 2013. "The Translation Process as object 
of Research". In The Routledge Handbook of T ranslation Studies, edited by Carmen Millän and Francesca Bartrina, 88-101. Abingdon and New York: Routledge. Harris, Mathew A., Caroline E. Brett, Wendy Johnson, and Ian J. Deary. 2016. "Personality Stability from Age 14 to Age 77 Years". Psychology and Aging 31(8): 862-874. Harzing, Anne-Wil. 2006. "Response Styles in Cross-National Survey Research: A 26-Country Study". International Journal of Cross-Cultural Management 6: 243-266. Henderson, John A. 1984. "Personality and the Linguist: A Comparison of the Personality Profiles of Professional Translators and Conference Interpreters". Dis sertation, University of Bradford. Hild, Adelina. 2014. "The Role of Self-Regulatory Processes in the Development of Interpreting Expertise". In Special Issue of Translation and Interpreting Studies 9(1): 128-149. Holmes, James S. 1988. "The Name and Nature of Translation Studies". In Translated! Papers on Literary Translation and Translation Studies, edited by James Holmes, 67-80. Amsterdam: Rodopi. Hubscher-Davidson, Severine. 2009. "Personal Diversity and Diverse Personalities in Translation: A Study of Individual Differences". Perspectives: Studies in Translatology 17(3): 175-192. - 2011. "A Discussion of Ethnographic Research Methods and Their Relevance for Translation Process Research". Across Languages and cultures 12(1): 1-18. - . 2013a. "Emotional Intelligence and Translation Studies: A New Bridge". Meta: Translators' Journal 58(2): 324-346. - 2013b. "The Role of Intuition in the Translation Process: A Case Study". Translation and Interpreting Studies 8(2): 211-232. - 2016. "Trait Emotional Intelligence and Translation: A Study of Professional T ranslators". Target 28(1): 132-157. - forthcoming. "Do Translation Professionals Need to Tolerate Ambiguity to Be Successful? A Study of the Links Between Tolerance of Ambiguity, Emotional Intelligence and Job Satisfaction". In American Translators Association Scholar ly Monograph Series, edited by Riitta Jääskeläinen and Isabel Lacruz. Amsterdam and Philadelphia: John Benjamins. Isle of Anglesey County Council. 2017. Translator Job Description. Accessed April 2017.

Mattheus, Gerald, Ian J. Deary, and Martha C. Whiteman. 2003. Personality Traits. Second edition. Cambridge and New York: Cambridge University Press.

Mavroveli, Stella, Kostantinos V. Petrides, Yolanda Sangareau, and Ndrian Furnham. 2009. "Exploring the Relationships Betueen Trait Emotional Intelligence and objective Socio-Emotional Dutcomes in Childhood". British Journal of Educational Psychology 79: 259-272. 
Mavroveli, Stella, and María José Sanchez-Ruiz. 2011. "Trait Emotional Intelligence Influences on Academic Achievement and School Behaviour". British Journal of Educational Psychology 81: 112-134.

Mayer, John D., and Peter Salovey. 1993. "The Intelligence of Emotional Intelligence". Intelligence 17(4): 433-442.

Mayer, John D., Peter Salovey, and David R. Caruso. 2008. "Emotional Intelligence: New Ability or Eclectic Traits?" American Psychologist 63: 503-517.

McCartney, Jamie L. 2016. "Is Grit the 'X-factor' for Interpreters Leaving the Profession?" Translation \& Interpreting 8(1): 30. McCrae, Robert R. 2002. "The Maturation of Personality Psychology: Adult Personality Development and Psychological Well-Being". Journal of Research in Personality 36: 307-317. Mccrae, Robert R., and Paul T. Costa, Jr. 1996. "Touard a New Generation of Personality Theories: Theoretical contexts for the Five-Factor Model". In The Five-Factor Model of Personality, edited by Jerry S. Wiggins, 51-87. New York: The Guildford Press. - 2008. "The Five-Factor Theory of Personality". In Handbook of Personality, edited by oliver P. John, Richard W. Robins, and Laurence A. Pervin, 159181. New York: The Guildford Press. —. 2012. Personality in Adulthood: A Five-Factor Theory Perspective. Second edition. New $Y$ ork and London: The Guilford Press. Mckinley, Sophia K., Emil R. Petrusa, Carina Fiedeldey-Van Dijk, John T. Mullen, Douglas S. Smink, Shannon E. Scott-Vernaglia, Tara S. Kent, w. Stephen Black-Schaffer, and Roy Phitayakorn. 2015. "A Multi-institutional Study of the Emotional Intelligence of Resident Physicians". The American Journal of Surgery 209(1): 26-33. Merlini, Raffaela. 2015. "Empathy: A 'Zone of Uncertainty' in Mediated Healthcare Practice". Cultus-The Journal of Intercultural Mediation and Communication 8: 27-49 Mikolajczak, Moïra. 2010. "Going Beyond the Ability-Trait Debate: The ThreeLevel Model of Emotional Intelligence". Sensoria: A Journal of Mind, Brain and Culture 5(2): 25-31. Mikolajczak, Moïra, Kerrin Bodarué, olivier Laloyaux et al. 2010. "Association Between Frontal EEG Asymmetries and Emotional Intelligence Among Adults". Personality and Individual Differences 48(2): 177-181. Mikolajczak, Moïra, and olivier Luminet. 2008. "T rait Emotional Intelligence and the Cognitive Appraisal of Stressful Events: An Exploratory Study". Personality and Individual Differences 44: $1445-1453$. 
Mikolajczak, Moïra, Olivier Luminet, Cécile Leroy, and Emmanuel Roy. 2007b. "Psychometric Properties of the Trait Emotional Intelligence Duestionnaire: Factor Structure, Reliability, Construct, and Incremental validity in a Frenchspeaking Population". Journal of Personality Assessment 88(3): 338-353. Mikolajczak, Moïra, clémentine Menil and olivier Luminet. 2007. "Explaining the Protective Effect of Trait Emotional Intelligence Regarding Dccupational Stress: Exploration of Emotional Labour Processes". Journal of Research in Personality 41(1): 107-1117. Mikolajczak, Moïra, K. V. Petrides, Nathalie Coumans et al. 2009. "The Moderating Effect of Trait Emotional Intelligence on Mood Deterioration Following Laboratory Induced Stress". International Journal of Clinical and Health Psychology 9(3):455-477. Mikolajczak, Moïra, Emmanuel Roy, olivier Luminet, Catherine Fillée, and Philippe de Timary. 2007a. "The Moderating Impact of Emotional Intelligence on Free Cortisol Responses to Stress". Psychoneuroendocrinology 32(8): 1000-1012. Mikolajczak, Moïra, Emmanuel Roy, Valêrie Verstrynge and olivier Luminet. 2009. "An Exploration of the Moderating Effect of Trait Emotional Intelligence on Memory and Attention in Neutral and Stressful Conditions". British Journal of Psychology 100: 699-715. Mischel, Walter, and Yuichi Shoda. 2008. "Touard a Unified Theory of Personality: Integrating Dispositions and Processing Dynamics within the Cognitive-Affective Processing System". In Handbook of Personality, edited by oliver P. John, Richard W. Robins, and Laurence A. Pervin, 208-241. New York: The Guildford Press. Momm, Tassilo, Gerhard Blickle, Yongmei Liu, Andreas Wihler, Mareike Kholin, and Jochen I. Menges. 2015. "It Pays to Have an Eye for Emotions: Emotion Recognition Ability Indirectly Predicts Annual Income". Journal of organizational Behavior 36(1): 147-163. Muñoz Martin, Ricardo. 2010a. "The way they Were: Subject Profiling in Translation Process Research". Copenhagen Studies in Language 38: 87-108. - 2010b. "0n Paradigms and Cognitive Translatology". In Translation and Cognition, edited by Gregory $M$. Shreve and Erik Angelone, 169-187. Amsterdam and Philadelphia: John Benjamins. 2012. "Standardizing Translation Process Research Methods and Reports". In Iberian Studies on Translation and Interpreting, edited by Isabel Garcia- Izquierdo and Esther Monzó, 11-22. 0xford: Peter Lang. - 2014. "A Blurred Snapshot of Advances in Translation Process Research". In Minding Translation, Special Issue of MonTI, edited by Ricardo Muñoz Martin, 49-84. San vicente del Raspeig: Publicaciones de la Universidad de Alicante. 2016a. "Reembedding Translation Process Research: An Introduction". In Reembedding Translation Process Research 
, edited by Ricardo Muñoz Martin, 1-19. Amsterdam and Philadelphia: John Benjamins Publishing Company. - . 2016b. "Of Minds and Men-Computers and Translators". Poznan Studies in Contemporary Linguistics 52(2): 351-381.

Nelis, Delphine, Jordi Quoidbach, Moïra Mikolajczak et al. 2009. "Increasing Emotional Intelligence: (How) Is It Possible?" Personality and Individual Differences 47: 36-41. Nilya, Yu, Phoebe C. Ellsworth, and Susumu Yamaguchi. 2006. "Amae in Japan and the United States: An Exploration of a 'Culturally Unique' Emotion". Emotion 6(2): 279-295.0'Brien, Sharon. 2012. "Translation as Human-Computer Interaction". Translation Spaces 1(1): 101-122. O'Connor, Peter, Jessica Nguyen, and Jeromy Anglim. 2017. "Effectively Coping with Task Stress: A Study of the validity of the Trait Emotional Intelligence Questionnaire-Short Form (TEIQue-SF)". Journal of Personality Assessment 99(3): 1-11. Datley, Keith, and P. N. Johnson-Laird. 2014. "Cognitive Approaches to Emotions". Trends in Cognitive sciences 18(3): 134-140. Ortony, Andrew, Donald A. Norman, and William Revelle. 2005. "Affect and Protoffect in Effective Functioning". In who Needs Emotions? The Brain Meets the Robot, edited by Jean-Marc Fellous and Michael A. Arbib, 173-202. Oxford: Oxford University Press. 0żańska-Ponikwia, Katarzyna. 2013. Emotions from a Bilingual Point of Vieu- Personality and Emotional Intelligence in Relation to Perception and Expression of Emotions in the L1 and L2. Newcastle upon Tyne: Cambridge Scholars Publishing. PACTE Group. 2011. "Results of the validation of the PACTE Translation Competence Model: Translation Project and Dynamic Translation Index". In Cognitive Explorations of Translation, edited by Sharon 0'Brien, 30-53. London and New York: Continuum Studies in Translation. Pavlenko, Aneta. 2008. "Emotion and Emotion-Laden Words in the Bilingual Lexicon". Bilingualism: Language and Cognition 11(2): 147-164. - 2012. "Affective Processing in Bilingual Speakers: Disembodied Cognition?" International Journal of Psychology 47(6): 405-428. Pérez-Gonzälez, Juan Carlos, and Maria-Jose Sanchez-Ruiz. 2014. "Trait Emotional Intelligence Anchored within the Big Five, Big Two and Big one Frameworks". Personality and Individual Differences 65: 53-58. Petrides, Kostantinos vasily. 2001. "A Psychometric Investigation into the Construct of Emotional Intelligence". Unpublished Doctoral Dissertation, University College London, UK. - 2004. "Empirical Findings from the Trait Emotional Intelligence Programme". Paper presented at the First European CERE Conference on Emotions, Amsterdam and The Netherlands. - $2009 a$. Technical Manual for the Trait Emotional Intelligence 
Questionnaire (TEIQue; 1st edition, 1st printing). London: London Psychometric Laboratory. - 2009b. "Psychometric Properties of the Trait Emotional Intelligence Questionnaire (TEIQue)". In Advances in the Measurement of Emotional Intelligence, edited by Con Stough, Donald $\mathrm{H}$. Saklofske, and James D. A. Parker, 85-101. New York: Springer.

- 2010. "Trait Emotional Intelligence Theory". Industrial and organizational Psychology 3: 136-139.

- 2011. "Ability and Trait Emotional Intelligence". In The Wiley-Blackwell Handbook of Individual Differences, edited by Tomas Chamorro-Premuzic, Sophie von Stumm, and Adrian Furnham, 656-678. Chichester: Wiley Blackuell. Petrides, Kostantinos $V$., Norah Frederickson, and Adrian Furnham. 2004. "The Role of Trait Emotional Intelligence in Academic Performance and Deviant Behavior at School". Personality and Individual Differences 36(2): 277-293. Petrides, Kostantinos V., Moïra Mikolajczak, Stella Mavroveli, Maria-Jose SanchezRuiz, Adrian Furnham, and Juan-Car los Pérez-González. 2016. "Developments in Trait Emotional Intelligence Research". Emotion Review 8(4): 1-7. Petrides, Kostantinos Vasily, Lisa Niven, and Thalia Mouskounti. 2006. "The Trait Emotional Intelligence of Ballet Dancers and Musicians". Psicothema 18: 101-107. Petrides, Kostantinos V., Ria Pita, and Flora Kokkinaki. 2007. "The Location of Trait Emotional Intelligence in Personality Factor Space". British Journal of Psychology 98(2): 273-289. Petrides, kostantinos $V$., Philip A. Vernon, Julie Aitken Schermer and Livia Veselka. 2011. "Trait Emotional Intelligence and the Dark Triad Traits of Personality". Twin Research and Human Genetics 14: 35-41. Phelps, Elizabeth A. 2006. "Emotion and Cognition: Insights from Studies of the Human Amygdala". Annual Review of Psychology 57: 27-53. Piirto, Jane. 2009. "The Personalities of Creative writers". In The Psychology of Creative writing, edited by Scott B. Kaufman and James C. Kaufman, 3-22. Cambridge: Cambridge University Press. Pourjalali, Samaneh, E. M. Skrzynecky, and James C. Kaufman. 2009. "The Creative Writer, Dysphoric Rumination, and Locus of Control". In The Psychology of Creative Writing, edited by Scott B. Kaufman and James C. Kaufman, 23-40. Cambridge: Cambridge University Press.Ramos Caro, Marina. 2016. "Testing Audio Narration: The Emotional Impact of Language in Audio Description". Perspectives 24(4): 606-634. Ramos Caro, Marina, and Ana Maria Rojo López. 2014. " 'Feeling' Audio Description: Exploring the Impact of $\mathrm{AD}$ on Emotional Response". Translation Spaces 3(1): 133-150. Reiss, Katarina. 2000. Translation 
Criticism. Manchester: St. Jerome Publishing. Revelle, William, and Klaus R. Scherer. 2009. "Personality (and Emotion)". In The 0xford Companion to Emotion and the Affective Sciences, edited by David Sander and Klaus R. Scherer, 304-305. Oxford: 0xford University Press. Risku, Hanna. 2014. "Translation Process Research as Interaction Research: From Mental to Socio-Cognitive Processes". In MonTi, edited by Ricardo Muñoz Martin, 331-353. San Vicente del Raspeig: Publicaciones de la Universidad de Alicante. Robinson, Michael D., Edward R. Watkins, and Eddie Harmon-Jones. 2013. "Cognition and Emotion: An Introduction". In Handbook of Cognition and Emotion, edited by Michael D. Robinson, Edward R. Watkins, and Eddie Harmon-Jones, 3-18. New York and London: The Guilford Press. Rodriguez-Castro, Mónica. 2016. "Intrinsic and Extrinsic Sources of Translator Satisfaction: An Empirical Study". Entreculturas 7-8: 195-229. Rojo, Ana. 2015. "Translation Meets cognitive Science: The Imprint of Translation on Cognitive Processing". Multilingua 34(6): 721-746. - - 2017. "The Role of Emotions". In Handbook of Translation and Cogni tion, edited by John $\mathrm{W}$. Schweiter and Aline Ferreira, 369-385. Hoboken: Wiley- Blackwell. Rojo, Ana, and Mar ina Ramos Caro. 2016. "Can Emotion Stir Translation Skill?" In Reembedding Translation Process Research, edited by Ricardo Muñoz Martin, 107-130. Amsterdam and Philadelphia: John Benjamins. Rojo, Ana, Marina Ramos, and Javier Valenzuela. 2014. "The Emotional Impact of Translation: A Heart Rate Study". Journal of Pragmatics 71: 31-44. Rose, Julie. 2013. "The Art of Hearing the voice". In Perspectives on Literature and Translation-Creation, Circulation, Reception, edited by Brian Nelson and Brigid Maher, 13-30. New York and London: Routledge. Rosiers, Alexandra, June Eyckmans, and Daniel Baumens. 2011. "A Story of Attitudes and Aptitudes? Investigating Individual Difference $v$ ariables Within the Context of Interpreting". Interpreting 13(1): 53-69. Russ, Sandra. 2009. "Pretend Play, Emotional Processes, and Developing Narratives". In The Psychology of Creative Writing, edited by Scott B. Kaufman and James C. Kaufman, 247-263. Cambridge: Cambridge University Press. Rydell, Ann-Margret, Lisa Berlin, and Gunilla Bohlin. 2003. "Emotionality, Emotion Regulation, and Adaptation Among 5-to 8-Year-0ld Children". Emotion 3(1): 30. Saldanha, Gabriela and Sharon 0'Brien. 2013. Research Methodologies in Translation Studies. London and New York: Routledge. Salovey, Peter and John D. Mayer. 1990. "Emotional Intelligence". Imagination, Cognition and Personality 9(3): 185-211. Schein, Jerome D. 1974. "Personality Characteristics Associated with Interpreter Proficiency". Journal of the American Deafness and Rehabilitation 
Association 7(3): 33-43. Scherer, Klaus. 2009. "Emotion Theories and concepts (Psychological Perspectives)". In The oxford Companion to Emotion and the Affective Sciences, edited by David Sander and Klaus R. Scherer, 145-151. Oxford: Oxford University Press. Schweda-Nicholson, Nancy. 2005a. "Personality Characteristics of Interpreter Trainees: The Myers-Briggs Type Indicator (MBTI)". The Interpreters' Newsletter 13: 109-142. - 2005b. "What Makes a Good Interpreter? A Study of Interpreter Trainees' Personality Traits". 국제회의 통멱과 번멱 7(2): 61-100.

Secret Intelligence Service MIG. 2017. Language Specialists. Accessed April 2017.

https://uuu.sis.gov.uk/language-specialist.html

Shao, Kaigi, WeiHuaYu, and zhongMin Ji. 2013. "The Relationship Between EFL Students' Emotional Intelligence and Writing Achievement". Innovation in Language Learning and Teaching 7: 107-124.

Shaw, Sherry, Sarka Timarova and Heidi Salaets. 2008. "Measurement of Cognitive and Personality Traits in Determining Aptitude of Spoken and Signed Language Interpreting Students". In Putting the Pieces Together: A Collaborative Approach to Educational Excellence, edited by Len Roberson and Sherry Shaw . University of North Florida: Conference of Interpreter Trainers.

Shields, Kathleen M., and Michael J. Clarke. (eds.) 2011. Translating Emotion: Studies in Transformation and Renewal Between Languages. 0xford: Peter Lang.

Siegling, Alexander B., Char lotte Nielsen, and K. V. Petrides. 2014. "Trait Emotional Intelligence and Leadership in a European Multinational Company". Personality and Individual Differences 65: 65-68.

Siegling, Alexander. B., K. V. Petrides, and Khatuna Martskuishvili. 2015. "An Examination of a New Psychometric Method for Optimizing Multi-Faceted Assessment Instruments in the Context of Trait Emotional Intelligence". European Journal of Personality 29(1): $42-54$.

Siegling, Alexander B., Donald H. Saklofske, Ashley K. Vesely, and David W. Nordstokke. 2012. "Relations of Emotional Intelligence with Gender-Linked Personality: Implications for a Refinement of EI Constructs". Personality and Individual Differences 52: 776-781. 
Siegling, Alexander B., Mireille Sfeir, and Hedley John Smyth. 2014. "Measured and Self-Estimated Trait Emotional Intelligence in a UK Sample of Managers". Personality and Individual Differences 65: 59-64.

Sjørup, Annette c. 2011. "Cognitive Effort in Metaphor Translation: An Eye Tracking Study". In Cognitive Explorations of Translation, edited by Sharon 0'Brien, 197214. London and New York: Continuum Studies in Translation.

Spranger, Eduard. 1920. Lebensformen:

Geistesuissenschaftliche Psychologie und Ethik der Persönlichkeit. Halle: M. Niemeyer.

Stern, Hans Heinrich. 1983. Fundamental Concepts of Language Teaching: Historical and Interdisciplinary Perspectives on Applied Linguistic Research. oxford: Oxford University Press.

Suri, Gaurav, Gal Sheppes, and James J. Gross. 2013. "Emotion Regulation and Cognition". In Handbook of Cognition and Emotion, edited by Michael D. Robinson, Edward R. Watkins, and Eddie Harmon-Jones, 195-209. New York and London: The Guilford Press.

Thorndike, Edward L. 1920. "Intelligence and Its Uses". Harper's Magazine 140: 227-235.

Timarovä, Särka, and Heidi Salaets. 2011. "Learning Styles, Motivation and Cognitive Flexibility in Interpreter Training: Self-Selection and Aptitude". Interpreting 13(1): $31-52$.

Tsaousis, Ioannis, and Smaragda Kazi. 2013. "Factorial Invariance and Latent Mean Differences of Scores on Trait Emotional Intelligence Across Gender and Age". Personality and Individual Differences 54(2): 169-173. United Nations Development Programme. 2017. Senior Translator/Interpreter, UNDP Iraq. Accessed April 2017.

https://jobs.undp.org/cj_view_job.cfm?cur_job_id= 36267 Uva, de Sousa M. C., Philippe de Timary, Marie Cortesi, Moïra Mikolajczak, Paul du Roy de Blicquy, and olivier Luminet. 2010. "Moderating Effect of Emotional Intelligence on the Role of Negative Affect in the Motivation to Drink in AlcoholDependent Subjects Undergoing Protracted Withdrawal". Personality and Individual Differences $48(1): 16-21$.

Vernon, Philip A., Vanessa C. Villani, Julie Aitken Schermer, and $k$. V. Petrides. 2008. "Phenotypic and 
Genetic Associations Between the Big Five and Trait Emotional Intelligence". Twin Research and Human Genetics 11(5): $524-530$.

Wilcox, Sherman. 1981. "The Myers-Briggs Type Indicator: Personality Types of Sign Language Students". Journal of Interpretation 1(1): $39-50$.

Wilson, Rosemary, and Jean-Marc Dewaele. 2010. "The Use of Web Questionnaires in Second Language Acquisition and Bilingualism Research". Second Language Research 26(1): 103-123.

Wranik, Tanja, Lisa Feldman Barrett, and Peter Salovey. 2007. "Intelligent Emotion Regulation". In Handbook of Emotion Regulation, edited by James J. Gross, 393-428. New York: The Guilford Press.

Zannirato, Alessandro. 2013. "The Quest for 'Perfection' Multidisciplinary Reflections on aptitude and Affect in Interpreter Selection and Training". The Interpreter and Translator Trainer 7(1): 107-127. 


\section{Emotion Perception}

-. 2013. "Communicating Emotions in a Foreign Language". In Applied Linguistics in the Age of Globalisation, CD-Rom, edited by A. Llances Baro, L. A. Ciro, L. Gallego Balsa, and R.M. Matea Serra, 16-26. Lleida: Edicions de la Universitat de Lleida. Elfenbein, Hillary A., and Nalini Ambady. 2003. "When Familiarity Breeds Accuracy: Cultural Exposure and Facial Emotion Recognition". Journal of Personality and Social Psychology 85(2): 276-290. Emmerich, Michael. 2013. "Beyond, Betueen: Translation, Ghosts, Metaphors". In In Translation-Translators on Their Work and what It Means, edited by Esther Allen and Susan Bernofsky, 44-57. New York: Columbia University Press. Gendron, Maria, Debi Roberson, Jacoba Marietta van der Vyver, and Lisa Feldman Barrett. 2014. "Perceptions of Emotion from Facial Expressions Are Not Culturally Universal: Evidence from a Remote Culture". Emotion 14(2): 251-262. Gross, James. 2008. "Emotion and Emotion Regulation: Personality Processes and Individual Differences". In Handbook of Personality, edited by oliver P. John, Richard W. Robins, and Lawrence A. Pervin, 701-724. New York: The Guildord Press. Guarino, Leticia, Derek Roger, and Daniel Thor 0lason. 2007. "Reconstructing N: A New Approach to Measuring Emotional Sensitivity". Current Psychology 26(1): 37-45. Halverson, Sandra L. 2014. "Reorienting Translation Studies: Cognitive Approaches and the Centrality of the Translator". In Translation: A Multidisciplinary Approach, edited by Juliane House, 116-139. Basingstoke and New York: Palgrave Macmillian. Herbert, Cornelia, Markus Junghofer, and Johanna Kissler. 2008. "Event Related Potentials to Emotional Adjectives During Reading". Psychophysiology 45: 487-498. Higgins, E. Tory, and Abigail A. Scholer. 2008. "When is Personality Revealed? A Motivated Cognition Approach". In Handbook of Personality: Theory and Research , edited by oliver P. John, Richard $W$. Robins, and Lawrence A. Pervin, 182-207. New York: The Guilford Press. Hvelplund, Kristian T., and Barbara Dragsted. forthcoming. "Genre Familiarity and Translation Processing: Differences and Similarities Between Literary and LSP Translators". In American Translators Association Scholar ly Monograph Series, edited by Riitta Jääskeläinen and Isabel Lacruz. Amsterdam and Philadelphia: John Benjamins. Holierhoek, J. 2008. "De Memoires Van een Moordenaar: Les Bienveillantes Vertaald". Filter 15(4): 3-11. Hubscher-Davidson, Severine. 2013. "The Role of Intuition in the Translation Process: A Case Study". Translation and Interpreting Studies 8(2): 211-232. 
Jääskeläinen, Riitta. 2012. "Translation Psychology". In Handbook of Translation Studies: volume 3 , edited by Yves Gambier and Luc Van Doorslaer, 191-197. Amsterdam and Philadelphia: John Benjamins.

Johnson, D. R., Huffman, B. L., Jasper, D. M. 2014. "Changing Race Boundary Perception by Reading Narrative Fiction". Basic and Applied Social Psychology 36(1): 83-90.

Jones, Francis R. 2011. Poetry Translating as Expert Action: Processes, Priorities and Networks. Amsterdam and Philadelphia: John Benjamins.

Kaplan, Alice. 2013. "Translation: The Biography of an Artform". In In Translation- Translators on Their Work and What It Means, edited by Esther Allen and Susan Bernofsky, 67-81. New York: Columbia University Press. Kenesei, Andrea. 2010. Poetry Translation Through Reception and Cognition: The Proof of Translation Is in the Reading. Newcastle: Cambridge Scholars Publishing. Kidd, David C., and Emanuele Castano. 2013. "Reading Literary Fiction Improves Theory of Mind". Science 342(6156): 377-380. King, Laura A. 1998. "Ambivalence Over Emotional Expression and Reading Emotions in Situations and Faces". Journal of Personality and Social Psychology 74: 753-762. Kinsella, John. 2011. "East Meets West: Some Portuguese Translations of Eastern Poetry". In Translating Emotion: Studies in Transformation and Renewal Between Languages, edited by Kathleen Shieds and Michael Clarke, 55-66. Bern: Peter Lang. Kissler, Johanna, Cornelia Herbert, Peter Peyk, and Markus Junghofer. 2007. "Buzzwords: Early Cortical Responses to Emotional Words During Reading". Psychological Science 18(6): 475-480. Kissler, Johanna, Cornelia Herbert, Irene Winkler, and Markus Junghofer. 2009. "Emotion and Attention in Visual Word Processing: An ERP Study". Biological Psychology 80(1): 75-83. Kolb, Waltraud. 2013. " "Who Are They?" Decision-Making in Literary Translation". In Tracks and Treks in Translation Studies: Selected Papers from the EST Congress, Leuven 2010, edited by Catherine Way, Sonia vandepitte, Reine Meylaerts, and Magdalena Bartlomiejczyk, 207-221. Amsterdam and Philadelphia: John Benjamins. Koster, Cees. 2014. "Literary Translation". In Translation: A Multidisciplinary Approach, edited by Juliane House, 140-157. Basingstoke and New $Y$ ork: Palgrave Macmillian.Lindquist, Kristen A., Lisa Feldman Barrett, Eliza Bliss-Moreau, and James A. Russell. 2006. "Language and the Perception of Emotion". Emotion 6(1): 125-138. Lindquist, Kristen A., and Maria Gendron. 2013. "What's in a Word? Language Constructs Emotion 
Perception". Emotion Review 5(1): 66-71. Lindquist, Kristen A., Tor D. Wager, Hedy Kober, Eliza Bliss-Moreau, and Lisa Feldman Barrett. 2012. "The Brain Basis of Emotion: A Meta-Analytic Review". Behavioral and Brain Sciences 35(3): 121-143. Magai, Carol. 2008. "Long-Lived Emotions: A Life Course Perspective on Emotional Development". In Handbook of Emotions, edited by Michael Lewis, Jeannette M. Haviland-Jones, and Lisa Feldman Barrett, 376-392. New York and London: The Guilford Press. Maier, Carol. 2002.

"Translation, Dépaysement, and Their Figuration". In Translation and Power, edited by Maria Tymoczko and Edwin Gentzler, 184-194. Amherst: University of Massachusetts Press. - 2006. "Translating as a Body: Meditations on Mediation (Excerpts 1994-2004)". In The Translator as Writer, edited by Susan Bassnett and Peter Bush, 137-148. London and New York: Continuum. Marsh, Abigail A., Hillary Anger Elfenbein, and Nalini Ambady. 2003. "Nonverbal 'Accents': Cultural Differences in Facial Expressions of Emotion". Psychological Science 14(4): 373-376. Martin, Rod A., Glen E. Berry, Tobi Dobranski, Marilyn Horne, and Philip G. Dodgson. 1996. "Emotion Perception Threshold: Individual Differences in Emotional Sensitivity". Journal of Research in Personality 30(2): 290-305. Mather, Mara, and Matthew R. Sutherland. 2011. "Arousal-Biased Competition in Perception and Memory". Perspectives on Psychological Science 6(2): 114-133. Momm, Tassilo, Gerhard Blickle, Yongmei Liu, Andreas Wihler, Mareike Kholin, and Jochen I. Menges. 2015. "It Pays to Have an Eye for Emotions: Emotion Recognition ability Indirectly Predicts Annual Income". Journal of Organizational Behavior 36(1): 147-163. Murphy, Fionnuala C., Michael P. Elubank, and Andrew J. Calder. 2012. "Emotion and Personality Factors Influence the Neural Response to Emotional Stimuli". Behavioral and Brain Sciences 35(3): 156-157. Neal, David. T. , and Tanya L. Chartrand. 2011. "Embodied Emotion Perception: Amplifying and Dampening Facial Feedback Modulates Emotion Perception Accuracy". Social Psychological and Personality Science 2(6): 673-678. 0'Sullivan, Carol. 2006. "Retranslating Ireland: Drality and Authenticity in French and German Translations of Blasket Island Autobiography". In Translating others 2, edited by Theo Hermans, 380-391. Manchester: St Jerome Publishing.

0żañska-Ponikwia, katarzyna. 2013. Emotions from a Bilingual Point of Vieu- Personality and Emotional Intelligence in Relation to Perception and Expression of Emotions in the L1 and L2. Newcastle upon Tyne: Cambridge Scholars Publishing. 
Petrides, Kostantinos $v$. 2009. Technical Manual for the Trait Emotional Intelligence Questionnaire (TEIdue; 1 st edition, 1st printing). London: London Psychometric Laboratory.

Petrides, Kostantinos V., and Adrian Furnham. 2003. "Trait Emotional Intelligence: Behavioural Validation in Tuo Studies of Emotion Recognition and Reactivity to Mood Induction". European Journal of Personality 57: 39-57.

-. 2006. "The Role of Trait Emotional Intelligence in a Gender-Specific Model of Organizational variables". Journal of Applied Social Psychology 36(2): 552-569. Phelps, Elizabeth A. 2006. "Emotion and Cognition: Insights from Studies of the Human Amygdala". Annual Review of Psychology 57: 27-53. Phelps, Elizabeth A., Sam Ling, and Marisa Carrasco. 2006. "Emotion Facilitates Perception and Potentiates the Perceptual Benefits of

Attention". Psychological Science 17(4): 292-299. Pinkham, Amy E., David L. Penn, Diana 0. Perkins, Karen A. Graham, and Monica Siegel. 2007. "Emotion Perception and Social Skill over the Course of Psychosis: A Comparison of Individuals 'at-Risk' for Psychosis and Individuals with Early and Chronic Schizophrenia Spectrum Illness". Cognitive Neuropsychiatry 12(3): 198-212. Poon, June M. L. 2004. "Career Commitment and Career Success: Moderating Role of EmotionPerception". Career Development International 9(4): 374-390. Porter, Catherine. 2013. "Translation as Scholarship". In In Translation-Translators on Their Work and what It Means, edited by Esther Allen and Susan Bernofsky, 58-66. New York: Columbia University Press. Pourtois, Gilles, Antonio Schettino, and Patrik Vuilleumier. 2013. "Brain Mechanisms for Emotional Influences on Perception and Attention: what is Magic and What Is Not". Biological Psychology 92: 492-512. Reynolds, Sian. 2014. "Affective Translation". Seminar, school of Advanced Study, University of London, May 10. Robinson, Douglas. 1991. The Translator's Turn. Baltimore: John Hopkins University Press. Rose, Julie. 2013. "The Art of Hearing the voice". In Perspectives on Literature and Translation-Creation, Circulation, Reception, edited by Brian Nelson and Brigid Maher, 13-30. New York and London: Routledge. Rutherford, Mel D., and Ashley M. Touns. 2008. "Scan Path Differences and Similarities During Emotion Perception in Those with and Without Autism Spectrum Disorders". Journal of Autism and Developmental Disorders 38(7): 1371-1381. Scherer, Klaus R., Elizabeth Clark-Polner, and Marcello Mortillaro. 2011. "In the Eye of the Beholder? Universality and Cultural Specificity in the Expression and Perception of Emotion". International 
Journal of Psychology 46(6): 401-435. Shields, Kathleen. 2011. "Auditory Images as Sites of Emotion: Translating Gerard Manley Hopkins into French". In Translating Emotion: Studies in Transformation and Renewal Between Languages, edited by Kathleen Shieds and Michael Clarke, 87-105. Bern: Peter Lang. Shields, Kathleen, and Michael Clarke. (eds.) 2011. "Introduction". In Translating Emotion: Studies in Transformation and Renewal Between Languages, edited by Kathleen Shieds and Michael clarke, 1-8. Bern: Peter Lang. Sleek, Scott. 2014. "Literary Character: Researchers Test Fiction as a Foundation for Empathy and Social skills". Observer 27(7). Accessed September 2014. wuw. 
Cole, Peter. 2013. "Waking Sense in Translation: Toward an Ethic of the Art". In In Translation-Translators on Their Work and what It Means, edited by Esther Allen and Susan Bernofsky, 3-16. New York: Columbia University Press. Dan-Glauser, Elise S., and James J. Gross. 2013. "Emotion Regulation and Emotion Coherence: Evidence for Strategy-Specific Effects". Emotion 13(5): 832-842. D'Avanzato, Catherine, and Jutta Joormann. 2013. "Emotion Regulation in Depression and Anxiety: Examining Diagnostic Specificity and Stability of Strategy use". Cognitive Therapy Research 37: 968-980. De Castella, Krista, Philippe Goldin, Hooria Jazaieri, Michal Ziv, Carol S. Dueck, and James J. Gross. 2013. "Beliefs About Emotion: Links to Emotion Regulation, Well-Being, and Psychological Distress". Basic and Applied Social Psychology 35(6): 497-505. EMT Expert Group, European Commission. 2009. "EMT Competences". Accessed January 2014.

http:/ec. europa. eu/dgs/translation/programmes/emt/key_docu ments/emt_competences_translators_en.pdf. English, Tammy , John P. Iliver, Sanjay Srivastava, and James J. Gross. 2012. "Emotion Regulation and Peer-Rated Social Functioning: A 4-Year Longitudinal Study". Journal of Research in Personality 46: 780-784. ERos Research Group. "About ERoS". Accessed January 2013. uulu. erosresearch. org/index. php/aboutz20eros/. Grant, Adam M. 2013. "Rocking the Boat but Keeping It Steady: The Role of Emo tion Regulation in Employee voice". Academy of Management Journal 56(6): 1703-1723. Gross, James J. $1998 a$.

"Antecedent- and Response-Focused Emotion Regulation: Divergent Consequences for Experience, Expression, and Physiology". Journal of Personality and Social Psychology 74: 224-237. —. 1998b. "The Emerging Field of Emotion Regulation: An Integrative Review". Review of General Psychology 2: 271-299. - - (ed.) 2007. Handbook of Emotion Regulation. New $Y$ ork: The Guilford Press. 2013. "Emotion Regulation: Taking Stock and Moving Foruard". Emotion 13(3): 359-365. Gross, James J., and oliver John. 2003. "Individual Differences in Two Emotion Regulation Processes: Implications for Affect, Relationships, and Well-Being". Journal of Personality and Social Psychology 85(2): 348-362. Gross, James J., and Ross A. Thompson. 2007. "Emotion Regulation: Conceptual Foundations". In Handbook of Emotion Regulation, edited by James J. Gross, 3-24. New York: The Guilford Press. Hansen, Gyde. 2005. "Experience and Emotion in Empirical Translation Research with Think-Aloud and Retrospection". Meta-Translators' Journal 50(2): 511-521. Hild, Adelina. 2014. "The Role of Self-Regulatory Processes in the 
Development of Interpreting Expertise". In Special Issue of Translation and Interpreting Studies 9(1): 128-149. John, oliver P., and James J. Gross. 2004. "Healthy and Unhealthy Emotion Regulation: Personality Processes, Individual Differences, and Life Span Development". Journal of Personality 72(6): 1301-1334. - 2007. "Individual Differences in Emotion Regulation". In Handbook of Emotion Regulation, edited by James J. Gross, 351-372. New York: The Guilford Press.

Kaplan, Alice. 2013. "Translation: The Biography of an Artform". In In Translation- Translators on Their Work and What It Means, edited by Esther Allen and Susan Bernofsky, 67-81. New York: Columbia University Press. Layder, Derek. 2004. Social and Personal Identity: Understanding Yourself. London and Thousand Daks, CA: Sage. Layton, Rebekah L., and Mark Muraven. 2014. "Self-Control Linked with Restricted Emotional Extremes". Personality and Individual Differences 58: 48-53. Lopes, Paulo N., John B. Nezlek, Natalio Extremera, Janine Hertel, Pablo FernándezBerrocal, Astrid Schütz, and Peter Salovey. 2011. "Emotion Regulation and the Duality of Social Interaction: Does the Ability to Evaluate Emotional Situations and Identify Effective Responses Matter?" Journal of Personality 79(2): 429-467. Matsumoto, David. 2006. "Are Cultural Differences in Emotion Regulation Mediated by Personality Traits?" Journal of Cross-Cultural Psychology 37(4): 421-437. Matsumoto, David, Yoo Seung Hee, and Sanae Nakagaua. 2008. "Culture, Emotion Regulation, and Adjustment". Attitudes and social Cognition 94(6): 925-937. McRae, Kateri, Megan S. Heller, oliver P. John, and James J. Gross. 2011. "ContextDependent Emotion Regulation: Suppression and Reappraisal at the Burning Man Festival". Basic and Applied Social Psychology 33: 346-350. Mesquita, Batja, and Dustin Albert. 2007. "The Cultural Regulation of Emotions". In Handbook of Emotion Regulation, edited by James J. Gross, 486-503. New York: The Guilford Press. Mikolajczak, Moïra, and olivier Luminet. 2008. "Trait Emotional Intelligence and the Cognitive Appraisal of Stressful Events: An Exploratory Study". Personality and Individual Differences 44: 1445-1453. Mikolajczak, Moïra, olivier Luminet, and Clëmentine Menil. 2006. "Predicting Resistance to Stress: Incremental validity of Trait Emotional Intelligence over Alexithymia and optimism". Psicothema 18: 79-88. Mikolajczak, Moïra, Clementine Menil, and olivier Luminet. 2007. "Explaining the Protective Effect of Trait Emotional Intelligence Regarding 0ccupational Stress: Exploration of Emotional Labour Processes". Journal of Research in Personality 41: 1107-1117. Mikolajczak, Moïra, Delphine Nelis, Michel Hansenne, and Jordi Quoidbach. 2008. "If You 
Can Regulate Sadness, You Can Probably Regulate Shame:

Associations Between Trait Emotional Intelligence, Emotion Regulation and Coping Efficiency Across Discrete

Emotions". Personality and Individual Differences 44: 1356-1368. Mikolajczak, Moïra, K. V. Petrides, and Jane Hurry. 2009. "Adolescents choosing Self-Harm as an Emotion Regulation Strategy: The Protective Role of Trait Emotional Intelligence". British Journal of Clinical Psychology 48: 181-193. Muñoz Martin, Ricardo. 2012. "Just a Matter of Scope-Mental Load in Translation Process Research".

Translation Spaces 1(1): 169-188. Murakami, Haruki. 2013. "As Translator, as Novelist". In In Translation-Translators on Their Work and what It Means, edited by Esther Allen and Susan Bernofsky, 169-182. New York: Columbia University Press. Neubert, Albrecht, and Gregory M. Shreve. 1992. Translation as Text. Kent: Kent State University Press. Niven, Karen, Daniel Holman, Peter Totterdell, and Tara Headley. 2012. "Does Regulating 0thers' Feelings Influence People's Dun Affective Well-Being?" Journal of Social Psychology 152(2): 246-260. Nolen-Hoeksema, Susan. 1991. "Responses to Depression and Their Effects on the Duration of Depressive Episodes". Journal of Abnormal Psychology 100(4): 569-582. 0żañska-Ponikwia, Katarzyna. 2013. Emotions from a Bilingual Point of Vieur Personality and Emotional Intelligence in Relation to Perception and Expression of Emotions in the L1 and L2. Newcastle upon Tyne: Cambridge Scholars Publishing. PACTE. 2009. "Results of the Validation of the PACTE Translation competence Model: Acceptability and Decision Making". Across Languages and Cultures 10(2): 207-230. Pavlenko, Aneta. 2008. "Emotion and Emotion-Laden Words in the Bilingual Lexicon". Bilingualism Language and Cognition 11(2): 147-164. Pennebaker, James $\mathrm{W}$., and Cindy K. Chung. 2011. "Expressive Writing and Its Links to Mental and Physical Health". In Dxford Handbook of Health Psychology, edited by Howard $S$. Friedman, 417-437. New York: 0xford University Press. Petrides, kostantinos $v$. 2009. Technical Manual for the Trait Emotional Intelligence Duestionnaire (TEIDue; 1st edition, 1st printing). London: London Psychometric Laboratory. Petrides, Kostantinos V., Juan Carlos Pérez-Gonzalez, and Adrian Furnham. 2007. "On the Criterion and Incremental validity of Trait Emotional Intelligence". Cognition and Emotion 21: 26-55. Petrides, Kostantinos $V$., Philip A. Vernon, Julie A. Schermer, Lannie Ligthart, Dorret I. Boomsma, and Livia Veselka. 2010. "Relationships Between Trait Emotional Intelligence and the Big Five in the Netherlands". Personality and Individual Differences 48: 906-910. Porter, Catherine. 2013. "Translation as Scholarship". In In Translation-Translators on Their Work and what It Means, 
edited by Esther Allen and Susan Bernofsky, 58-66. New York: Columbia University Press. Prospects. 2012.

"Postgraduate Study". Accessed January 2014.

uulu. prospects.

ac.uk/postgraduate_study_why_do_postgraduate_study.htm.

Rimé, Bernard. 2007. "Interpersonal Emotion Regulation". In Handbook of Emotion Regulation, edited by James J. Gross, 466-485. New York: The Guilford Press.

Rydell, Ann-Margret, Lisa Berlin, and Gunilla Bohlin. 2003. "Emotionality, Emotion Regulation, and Adaptation Among 5-8-Year-0ld Children". Emotion 3(1): 30-47.

Sapolsky, Robert, M. 2007. "Stress, Stress-Related Disease, and Emotional Regulation". In Handbook of Emotion Regulation, edited by James J. Gross, 606-615. New York: The Guilford Press.

Suri, Gaurav, Gal Sheppes, and James J. Gross. 2013. "Emotion Regulation and Cognition". In Handbook of Cognition and Emotion, edited by Michael D. Robinson, Edward R. Watkins, and Eddie Harmon-Jones, 195-209. New York: The Guilford Press.

Tamir, Maya, and Michael D. Robinson. 2004. "Knowing Good from Bad: The Paradox of Neuroticism, Negative Affect, and Evaluative Processing". Journal of Personality and Social Psychology 87: 913-925.

Totterdell, Peter, Sandy M. Hershcovis, Karen Niven, Tara Reich, and Chris Stride. 2012. "Can Employees Be Emotionally Drained by Witnessing Unpleasant Interactions Betueen Co-Workers? A Diary Study on Induced Emotion Regulation". Work \& Stress 26(2): 112-129. T ymoczko, Maria, and Eduin Gentzler. (eds.) 2002. Translation and Pouer. Amherst: University of Massachusetts Press. Tyulenev, Sergey. 2012. Applying Luhmann to Translation Studies: Translation in Society. New York: Routledge. University of Portsmouth. "Talking with the Translators". Accessed January 2014.

uuw port .ac. uk/translation/talking-with-the-translators/. Verhaeghen, Paul, Jutta Joorman, and Rodney Khan. 2005. "Why we sing the Blues: The Relation Between Self-Reflective Rumination, Mood, and Creativity". Emotion 5(2): 226-232. Weaver, William. 1989. "The Process of Translation". In The Craft of Translation, edited by John Biguenet and Rainer Shulte, 117-125. Chicago: Chicago University Press. Webb, Thomas L., Eleanor Miles, and Paschal Sheeran. 2012. "Dealing with Feeling: A 
Meta-Analysis of the Effectiveness of Strategies Derived from the Process Model of Emotion Regulation".

Psychological Bulletin 138(4): 775-808. Weinberger, Eliot. 2013. "Anonymous Sources-0n Translators and Translation". In In Translation-Translators on Their Work and what It Means, edited by Esther Allen and Susan Bernofsky, 17-30. New York: Columbia University Press. Wranik, Tanja, Lisa Feldman Barrett, and Peter Salovey. 2007. "Intelligent Emotion Regulation". In Handbook of Emotion Regulation, edited by James J. Gross, 393-407. New York: The Guilford Press. Yoo, Seung Hee, David Matsumoto, and Jeffrey A. LeRoux. 2006. "The Influence of Emotion Recognition and Emotion Regulation on Intercultural Adjustment".

International Journal of Intercultural Relations 30(3): 345-363. 


\section{Emotion Expression}

Holierhoek, Jeanne. 2008. "De Memoires Van een Moordenaar: Les Bienveillantes Vertaald". Filter 15(4): 3-11.

Hubscher-Davidson, Séverine. 2016. "Trait Emotional Intelligence and Translation: A Study of Professional Translators". Target 28(1): 132-157. - forthcoming. "Do Translation Professionals Need to Tolerate Ambiguity to be Successful? A Study of the Links Between Tolerance of Ambiguity, Emotional Intelligence and Job Satisfaction". In American Translators Association Scholar ly Monograph Series, edited by Riitta Jääskeläinen and Isabel Lacruz. Amsterdam and Philadelphia: John Benjamins. Jääskeläinen, Riitta. 2012. "Translation Psychology". In Handbook of Translation Studies 3 , edited by Yves Gambier and Luc van Doorslaer, 191-198. Amsterdam and Philadelphia: John Benjamins. Jones, Francis R. 2011. Poetry Translating as Expert Action: Processes, Priorities and Networks. Amsterdam and Philadelphia: John Benjamins. Kafetsios, Konstantinos, and Leonidas A. Zampetakis. 2008. "Emotional Intelligence and Job Satisfaction: Testing the Mediatory Role of Positive and Negative Affect at Work". Personality and Individual Differences 44: 712-722. Kaplan, Alice. 2013. "Translation: The Biography of an Artform". In In Translation- Translators on Their Work and what It Means, edited by Esther Allen and Susan Bernofsky, 67-81. New York: Columbia University Press. Kashdan, Todd, and Robert Bisuas-Diener. 2014. The upside of Your Dark Side: Why Being Your whole Self-Not Just Your "Good" Self-Drives Success and Fulfillment. New York: Penguin Group. Kaufman, James C., and Janel D. Sexton. 2006. "Why Doesn't the Writing Cure Help Poets?" Review of General Psychology 10(3): 268. Kennedy-Moore, Eileen, Melanie A. Greenburg, and Camille B. Wortman. 1991. "Varieties of Nonexpression: A Review of Self-Report Measures of Emotional Control". Paper presented at the meeting of the American Psychological Association, San Francisco, CA. Kennedy-Moore, Eileen, and Jeanne C. Watson. 2001a. Expressing Emotion: Myths, Realities, and Therapeutic Strategies. New York: The Guilford Press. - 2001b. "How and when Does Emotional Expression Help?" Review of General Psychology 5(3): 187-212. King, Laura A., and Kathi N. Miner . 2000. "Writing About the Perceived Benefits of Traumatic Events: Implications for Physical Health". Personality and Social Psychology Bulletin 26(2): 220-230. Kirk, Beverley A., Nicola S. Schutte, and Donald w. Hine. 2011. "The Effect of an Expressive-writing Intervention for Employees on Emotional Self-Efficacy, Emotional Intelligence, Affect, and Workplace Incivility". Journal of 
Applied Social Psychology 41(1): 179-195. Klein, Kitty, and Adriel Boals. 2001. "Expressive Writing Can Increase Working Memory Capacity". Journal of Experimental Psychology: General 130(3): 520. Kolb, Waltraud. 2013. 'Who Are They?' Decision-Making in Literary Translation". In Tracks and Treks in Translation Studies: Selected Papers from the EST Congress, Leuven 2010, edited by Catherine Way, Sonia Vandepitte, Reine Meylaerts, and Magdalena Bartlomiejczyk, 207-221. Amsterdam and Philadelphia: John Benjamins. - - 2017. "It Was on my Mind all Day": Literary Translators Working from Home Some Implications of Workplace Dynamics". Translation Spaces 6(1): 27-43. Koster, Cees. 2014. "Literary Translation". In Translation: A Multidisciplinary Approach, edited by Juliane House, 140-157. Basingstoke and New York: Palgrave Macmillian. Krueger, Joel. 2014. "Dewey's Rejection of the Emotion/Expression Distinction". In Neuroscience, Neurophilosophy and Pragmatism: Brains at Work with the World, edited by Tibor Solymosi and John R. Shook, 140-161. Basingstoke and New York: Palgrave Macmillan. Künzli, Alexander. 2004. "Risk Taking: Trainee Translators vs. Professional Translators- A Case Study". JoSTrans 2: 34-49. Lehr, Caroline. 2014. "The Influence of Emotion on Language Performance-Study of a Neglected Determinant of Decision-Making in Professional Translators". Dissertation, University of Geneva. Linley, P. Alex, Aimee Felus, Raphael Gillett, and Stephen Joseph. 2011. "Emotional Expression and Growth Following Adversity: Emotional Expression Mediates Subjective Distress and Is Moderated by Emotional Intelligence". Journal of Loss and Trauma 16(5): 387-401. Lu, Qian, and Annette L. Stanton. 2010. "How Benefits of Expressive Writing vary as a Function of writing Instructions, Ethnicity and Ambivalence 0ver Emotional Expression". Psychology and Health 25(6): 669-684. MacRobert, Marguerite. 2012. "Exploring an Acting Method to Contain the Potential Madness of the Creative Writing Process: Mental Health and writing with Emotion". New Writing 9(3): 349-360. Maier, Carol. 2002. "Translation, Dépaysement, and Their Figuration". In Translation and Power, edited by Maria Tymoczko and Edwin Gentzler, 184-194. Amherst: University of Massachusetts Press. Martin, Elizabeth A., and John G. Kerns. 2011. "The Influence of Positive Mood on Different Aspects of Cognitive Control". Cognition and Emotion 25(2): 265-279. Nelson, Brian and Brigid Maher. 2013. Perspectives on Literature and Translation- Creation, Circulation, Reception. New York and London: Routledge. Niles, Andrea N., Kate E. Byrne Haltom, Catherine M. Mulvenna, Matthew D. Lieberman, and Annette L. Stanton. 2014. "Randomized Controlled Trial of Expressive Writing 
for Psychological and Physical Health: The Moderating Role of Emotional Expressivity". Anxiety, Stress \& Coping 27(1): 1-17. Park, Daeun, Gerardo Ramirez, and Sian L. Beilock. 2014. "The Role of Expressive W riting in Math Anxiety". Journal of Experimental Psychology: Applied 20(2): 103-111. Parker-Pope, Tara. 2015. "Writing Your Way to Happiness". The New York Times. Accessed June 2016. http://mobile. nyt imes. com/blogs/well/2015/01/19/ur it ingyour-way-to-happiness/?ref=health\&_r=18referrer .

Pauley, Perry M., Mark T. Morman, and Kory Floyd. 2011. "Expressive Writing Improves Subjective Health Among Testicular Cancer Survivors: A Pilot Study". International Journal of Men's Health 10(3): 199-219. Pennebaker, James. W. 1997. "Writing About Emotional Experiences as a Therapeutic Process". Psychological Science 8(3): 162-166. -. 2012. Dpening Up: The Healing Power of Expressing Emotions. New York: The Guilford Press. Pennebaker, James $W$. , and Sandra K. Beall. 1986. "Confronting a Traumatic Event: Toward an Understanding of Inhibition and Disease". Journal of Abnormal Psychology 95(3): 274-281. Pennebaker, James $W$., and Cindy $K$. Chung. 2011. "Expressive Writing and Its Links to Mental and Physical Health". In 0xford Handbook of Health Psychology, edited by Howard $S$. Friedman, 417-437. New York: Oxford University Press. Pennebaker, James W., and Anna Graybeal. 2001. "Patterns of Natural Language Use: Disclosure, Personality, and Social Integration". Current Directions in Psychological science 10(3): 90-93. Pennebaker, James $W$. , and Janel D. Seagal. 1999. "Forming a Story: The Health Benefits of Narrative". Journal of Clinical Psychology 55(10): 1243-1254. Petrides, Kostantinos $v$. 2009. Technical Manual for the Trait Emotional Intelligence Questionnaire (TEIQue; 1st edition, 1st printing). London: London Psychometric Laboratory. Pluth, Kate M. 2012. "Alexithymia, Emotional Intelligence, and Their Relation to Word Usage in Expressive Writing". Scripps Senior Theses, Paper 36. Radcliffe, Alison M., Mark A. Lumley, Jessica Kendall, Jennifer K. Stevenson, and Joyce Beltran. 2010. "Written Emotional Disclosure: Testing whether Social Disclosure Matters". Journal of Social and Clinical Psychology 26(3): 362-384. Ramirez, Gerardo, and Sian L. Beilock. 2011. "Writing About Testing Horries Boosts Exam Performance in the Classroom". Science 331(6014): 211-213. Richards, Ivor A. 1953. "Toward a Theory of Translating". In Studies in Chinese Thought, edited by Arthur $F$. Wright, 247-262. Chicago: University of Chicago Press. Richards, Jane M., Wanda E. Beal, Janel D. Seagal, and James W. Pennebaker. 2000. "Effects of Disclosure of Traumatic Events on Illness Behavior Among Psychiatric Prison Inmates". Journal of Abnormal 
Psychology 109(1): 156-160. Rojo, Ana. 2017. "The Role of Emotions". In Handbook of Translation and Cognition, edited by John $w$. Schweiter and Aline Ferreira, 369-385. Hoboken: Wiley-Blackwell. Rojo, Ana and Marina Ramos Caro. 2016. "Can Emotion Stir Translation Skill? Defining the Impact of Positive and Negative Emotions on Translation Performance". In Reembedding Translation Process Resarch, edited by Ricardo Muñoz Martin, 107-129. Amsterdam and Philadelphia: John Benjamins. Rose, Julie. 2013. "The Art of Hearing the voice". In Perspectives on Literature and Translation-Creation, circulation, Reception, edited by Brian Nelson and Brigid Maher, 13-30. New York and London: Routledge. Rosenberg, Harriet J., Stanley D. Rosenberg, Marc S. Ernstoff, George L. Wolford, Robert J. Amdur, Mary R. Elshamy, Susan M. Bauer-Wu, Tim A. Ahles, and James $\mathrm{W}$. Pennebaker. 2002. "Expressive Disclosure and Health Dutcomes in a Prostate Cancer Population". The International Journal of Psychiatry in Medicine 32(1): 37-53. Shao, Kaidi, WeiHua Yu, and zhongMin Ji. 2013. "The Relationship Between EFL Students' Emotional Intelligence and Hriting Achievement". Innovation in Language Learning and Teaching 7(2): 107-124. Sheldon, Kennon M., and Sonja Lyubomirsky. 2006. "How to Increase and Sustain Positive Emotion: The Effects of Expressing Gratitude and Visualizing Best Possible Selves". The Journal of Positive Psychology 1(2): 73-82. Sloan, Denise M., Brian P. Marx, and Eva M. Epstein. 2005. "Further Examination of the Exposure Model Underlying the Efficacy of Written Emotional Disclosure". Journal of Consulting and Clinical Psychology 73(3): 549. Sloan, Denise M., Brian P. MarX, and Eva M. Greenberg. 2011. "A Test of Written Emotional Disclosure as an Intervention for Posttraumatic Stress Disorder". Behaviour Research and Therapy 49(4): 299-304. Smyth, Joshua. M., James W. Pennebaker, and Danielle Arigo. 2012. "What Are the Health Effects of Disclosure?" In Handbook of Health Psychology, edited by Andrew Baum, Tracey A. Revenson, and Jerome Singer, 175-192. Hove and New York: Psychology Press. Stickney, Lisa T. 2010. "Who Benefits from Pennebaker's Expressive Writing? More Research Recommendations: A Commentary on Range and Jenkins". Sex Roles 63(34): 165-172. Suanbon, Thomas, Lindsay Boyce, and Melanie A. Greenberg. 2008. "Expressive Writing Reduces Avoidance and Somatic complaints in a Community Sample with Constraints on Expression". British Journal of Health Psychology 13(1): 53-56. Tamagawa, Rie, Rona Moss-Morris, Alexandra Martin, Elizabeth Robinson, and Roger J. Booth. 2013. "Dispositional Emotion Coping Styles and Physiological Responses to Expressive Writing". British Journal of Health Psychology 18(3): 574-592. Totterdell, Peter and Karen Niven. 2014. Workplace Moods and Emotions: 
A Review of Research. Char leston: Createspace Independent Publishing.

Ullrich, Philip M., and Susan K. Lutgendorf. 2002.

"Journaling About Stressful Events: Effects of Cognitive Processing and Emotional Expression". Annals of Behavioral Medicine 24(3): 244-250. Weinberger, Eliot. 2013.

"Anonymous Sources-0n Translators and Translation". In In Translation-Translators on Their work and what It Means, edited by Esther Allen and Susan Bernofsky, 17-30. New York: Columbia University Press. Wiener, Morton, and Albert Mehrabian. 1968. Language Within Language: Immediacy, a Channel in Verbal Communication. New York:

Appleton-Century-Crofts. Wing, Joanna F., Nicola S. Schutte, and Brian Byrne. 2006. "The Effect of Positive Writing on Emotional Intelligence and Life Satisfaction". Journal of clinical Psychology 62(10): 1291-1302. Wittuer, Michael. 2007. "Emotion and Translation: Using the Example of Popularising Medical Texts in Paediatrics". In Evidence-Based LSP: Translation, Text and Terminology, edited by Khurshid Ahmad and Margaret Rogers, 345-356. Bern: Peter Lang. Zakouski, Sandra G., Michele Herzer, Sara Dittoe Barrett, Jessica Gerfen Milligan, and Nancy Beckman. 2011. "Who Benefits from Emotional Expression? An Examination of Personality Differences Among Gynaecological Cancer Patients Participating in a Randomized Controlled Emotional Disclosure Intervention Trial". British Journal of Psychology102(3): 355-372. 


\section{Discussion}

Hild, Adelina. 2014. "The Role of Self-Regulatory Processes in the Development of Interpreting Expertise". In Special Issue of Translation and Interpreting Studies 9(1): $128-149$.

Hoyt, Michael A., Jennifer Austenfeld, and Annette L. Stanton. 2016. "Processing Coping Methods in Expressive Essays fbout Stressful Experiences: Predictors of Health Benefit". Journal of Health Psychology 21(6): 1183-1193.

Hubscher-Davidson, Séverine. 2016. "Trait Emotional Intelligence and Translation". Target: International Journal of Translation Studies 28(1): 132-157.

-. forthcoming. "Do Translation Professionals Need to Tolerate Ambiguity to Be Successful? A Study of the Links Between Tolerance of Ambiguity, Emotional Intelligence and Job Satisfaction". In American Translators Association Scholarly Monograph Series, edited by Riitta Jääskeläinen and Isabel Lacruz. Amsterdam and Philadelphia: John Benjamins. Hvelplund, Kristian T., and Barbara Dragsted. forthcoming. "Genre Familiarity and Translation Processing: Differences and Similarities Between Literary and LSP Translators". In American Translators Association Scholarly Monograph Series, edited by Riitta Jääskeläinen and Isabel Lacruz. Amsterdam and Philadelphia: John Benjamins. Kotsou, Ilios, Delphine Nelis, Jacques Grégoire, and Moïra Mikolajczak. 2011. "Emotional Plasticity: Conditions and Effects of Improving Emotional competence in Adulthood". Journal of Applied Psychology 96(4): 827-839. Lee-Jahnke, Hannelore. 2005. "Processes and Pathways in Translation and Interpretation". Meta 50(2): 337-794. Magai, Carol. 2008. "Long-Lived Emotions: A Life Course Perspective on Emotional Development". In Handbook of Emotions, Third edition, edited by Michael Lewis, Jeannette M. Haviland-Jones, and Lisa Feldman Barrett, 376-392. New York and London: The Guilford Press. Martins, Alexandra, Nelson Ramalho, and Estelle Morin. 2010. "A Comprehensive Meta-Analysis of the Relationship Between Emotional Intelligence and Health". Personality and Individual Differences 49(6): 554-564. Massey, Gary. 2017. "Translation Competence Development and Process-oriented Pedagogy". In Handbook of Translation and Cognition, edited by John W. Schweiter and Aline Ferreira, 496-518. Hoboken: Wiley-Blackwell.

Mattheus, Gerald, Moshe Zeidner, and Richard D. Roberts. 2017. "Emotional Intelligence, Health, and Stress". The 
Handbook of Stress and Health: A Guide to Research and Practice 1: 312-326. Mccartney, Jamie L. 2016. "Is Grit the ' $x$-factor' for Interpreters Leaving the Profession?" Translation \& Interpreting 8(1): 30-51. Miao, Chao, Ronald H. Humphrey, and Shanshan Qian. 2017a. "Are the Emotionally Intelligent Good Citizens or Counterproductive? A Meta-Analysis of Emotional Intelligence and Its Relationships with Organizational Citizenship Behaviour and Counterproductive Work Behavior". Personality and Individual Differences 116: 144-156. - 2017b. "A Meta-Analysis of Emotional Intelligence Effects on Job Satisfaction Mediated by Job Resources, and a Test of Moderators". Personality and Individual Differences 116: 281-288. Mikolajczak, Moïra, and Sébastien Van Bellegem. 2017. "Increasing Emotional Intelligence to Decrease Healthcare Expenditures: How Profitable Would It Be?" Personality and Individual Differences 116: 343-347. Nelis, Delphine, Ilios Kotsou, Jordi Duoidbach, Michel Hansenne, Fanny Weytens, Pauline Dupuis, and Moira Mikolajczak. 2011. "Increasing Emotional Competence Improves Psychological and Physical Well-Being, Social Relationships, and Employability". Emotion 11(2): 354-366. Petrides, Kostantinos $V$. 2009. Technical Manual for the Trait Emotional Intelligence Questionnaire (TEIdue; 1 st edition, 1st printing). London: London Psychometric Laboratory. Petrides, Kostantinos $V$. , Norah Frederickson, and Adrian Furnham. 2004. "The Role of Trait Emotional Intelligence in Academic Performance and Deviant Behavior at School". Personality and Individual Differences 36(2): 277-293. Petrides, Kostantinos V., Moïra Mikolajczak, Stella Mavroveli, Maria-Jose SanchezRuiz, Adrian Furnham, and Juan-Car los Pérez-Gonzälez. 2016. "Developments in Trait Emotional Intelligence Research". Emotion Revieu 8(4): 335-341. Rodriguez-Castro, Mónica. 2016. "Intrinsic and Extrinsic Sources of Translator Satisfaction: An Empirical study". Entreculturas 7-8: 195-229. Rojo, Ana, and Marina Ramos Caro. 2016. "Can Emotion Stir Translation Skill?" In Reembedding Translation Process Research, edited by Ricardo Muñoz Martin, 107-130. Amsterdam and Philadelphia: John Benjamins. Sänchez-Ruiz, María José, Juan Carlos Perez-Gonzalez, and Kostantinos V. Petrides. 2010. "Trait Emotional Intelligence Profiles of Students from Different University Faculties". Australian Journal of Psychology 62(1): 51-57. Schutte, Nicola S., John M. Malouff, and Einar B. Thorsteinsson. 2013. "Increasing Emotional Intelligence Through Training: Current Status and Future Directions". International Journal of Emotional Education 5(1): 56-72. Seeley, Saren H., Betina Yanez, Annette L. Stanton, and Michael A. Hoyt. 2017. "An Emotional Processing writing Intervention and Heart Rate 
Variability: The Role of Emotional Approach". Cognition and Emotion 31(5): 988-994. Shao, Kaidi, WeiHua Yu, and ZhongMin Ji. 2013. "The Relationship Between EFL Students' Emotional Intelligence and Writing Achievement". Innovation in Language Learning and Teaching 7(2): 107-124. Shreve, Gregory M., and Erik Angelone. 2011. "Uncertainty Management, Metacognitive Bundling in Problem-Solving and Translation Quality". In Cognitive Explorations of Translation, edited by Sharon 0'Brien, 108-130. London: Continuum. Siegling, Alexander B., K. V. Petrides, and Khatuna Martskvishvili. 2015. "An Examination of a New Psychometric Method for Optimizing Multi-Faceted Assessment Instruments in the context of Trait Emotional Intelligence". European Journal of Personality 29(1): 42-54. Siegling, Alexander B., Ashley K. Vesely, and Donald H. Saklofske. 2013. "Advancing the Trait EI Content Domain: Further Evidence for the Distinctiveness of Interpersonal Facets". Personality and Individual Differences 54(1): 81-86. Tiselius, Elisabet, and Adelina Hild. 2017. "Expertise and Competence in Translation and Interpreting". In Handbook of Translation and Cognition, edited by John W. Schweiter and Aline Ferreira, 425-444. Hoboken: Wiley-Blackwell. Zeidner, Moshe, and Gerald Matthews. 2017. "Emotional Intelligence in Gifted Students". Gifted Education International 33(2): 163-182. 


\section{Conclusion and Future Directions}

Burnett, Dean. 2015. "Calm Down, Dear: The Dark Side of 'Emotional Intelligence' ". The Guardian. Accessed June 2017. umu. theguardian.com/science/

brain-f lapping/2015/apr/21/calm-doun-dear -emot ional-intelligence-psycho logy.

Chesterman, Andrew. 2013. "Models of what Processes?" Translation and Interpreting Studies 8(2): 155-168.

Colino, Stacey. 2016. "Are You Catching 0ther People's Emotions?" U.S. Neus. Accessed June 2017.

http://health. usnews. com/health-neus/health-uellness/

Craig, Scotty D., Sidney D'Mello, Amy $w$ itherspoon, and Art Graesser. 2008. "Emote Aloud During Learning with AutoTutor: Applying the Facial Action Coding system to Cognitive-Affective States During Learning". Cognition and Emotion 22(5): 777-788.

D'Mello, Sidney, and Caitlin Mills. 2014. "Emotions while Writing About Emotional and Non-Emotional Topics". Motivation and Emotion 38(1): 140-156.

Dam, Helle V., and Kaisa Koskinen. 2012. "The Translation Profession: Centers and Peripheries". Call for panel papers, 7th EST Congress, Germersheim, 2013. Accessed June 7 2017. udu. fbo6.uni-mainz.de/est/62. php.

Dam, Helle $V$., and Karen Zethsen. 2016. "I Think It Is a Wonderful Job' On the Solidity of The Translation Profession". Journal of Specialised Translation 25: 174-187.

Damasio, Antonio R. 1994. Descartes' Error: Emotion, Rationality and the Human Brain. New York: Putnam Grosset Books).

Göpferich, Susanne, and Riitta Jääskeläinen. 2009. "Process Research into the Development of Translation Competence: Where Are We, and where Do we Need to Go?" Across Languages and Cultures 10(2): 169-191.

Grieve, Rachel, and Doug Mahar. 2010. "The Emotional Manipulation-Psychopathy Nexus: Relationships with Emotional Intelligence, Alexithymia and Ethical Position". Personality and Individual Differences 48(8): 945-950.

Jones, Francis R. 2011. Poetry Translating as Expert 
Action: Processes, Priorities and Networks. Amsterdam and Philadelphia: John Benjamins.

Kang, Sun-Mee, and Phillip R. Shaver. 2004. "Individual

Differences in Emotional Complexity: Their Psychological Implications". Journal of Personality 72(4): 687-726.

Lofthouse, Gracie. 2015. "How Language Influences Emotion". The Atlantic. Accessed June 2017.

Mikolajczak, Moira. 2010. "Going Beyond the ability-T rait Debate: The ThreeLevel Model of Emotional Intelligence". Sensoria: A Journal of Mind, Brain and Culture 5(2): $25-31$.

Risku, Hanna. 2014. "T ranslation Process Research as Interaction Research: From Mental to Socio-Cognitive Processes". In MonTi, edited by Ricardo Muñoz Martin, 331-353. San Vicente del Raspeig: Publicaciones de la Universidad de Alicante.

Rojo, Ana. 2017. "The Role of Emotions". In Handbook of Translation and Cognition, edited by John $W$. Schueiter and Aline Ferreira, 369-385. Hoboken: Wiley-Blackuell.

Schutte, Nicola S., John M. Malouff, and Einar B. Thorsteinsson. 2013. "Increasing Emotional Intelligence Through Training: Current Status and Future Directions". International Journal of Emotional Education 5(1): 56-72.

Whyatt, Bogusłaua. 2012. Translation as a Human Skill: From Predisposition to Expertise. Poznañ: Wydaunictuo Naukoue UAM. 